\title{
Analisis Sekuens DNA Penyandi 18S rRNA pada Tumbuhan Cocor Bebek (Kalanchoe $x$ laetivirens)
}

\author{
(Analysis of DNA Sequences Encoding 18S rRNA \\ in Cocor Bebek (Kalanchoe $x$ laetivirens)
}

Felly Andariyusti, Dewi Indriyani Roslim*

\begin{abstract}
Jurusan Biologi, Fakultas Matematika dan Ilmu Pengetahuan Alam, Universitas Riau, Kampus Bina Widya, Jl. HR Soebrantas Km 12.5, Panam, Pekanbaru 28293, Riau, Indonesia.

*Email korespondensi: dewiindriyaniroslim@gmail.com
\end{abstract}

(Article History: Received January 16, 2021; Revised April 6, 2021; Accepted April 13, 2021)

\begin{abstract}
ABSTRAK
Studi mengenai stress pada tumbuhan semakin banyak didasarkan pada ekspresi gen. Gen penyandi $18 S$ rRNA merupakan salah satu anggota dari gen housekeeping yang umum digunakan sebagai kontrol internal. Penelitian ini bertujuan untuk menganalisis sekuens DNA penyandi $18 S$ rRNA pada tumbuhan cocor bebek (K. x laetivirens). Metode penelitian meliputi ekstraksi DNA total dari daun segar menggunakan Mini Kit Genomic DNA Mini Kit Plant (Geneaid). Data sekuen DNA diolah menggunakan program BioEdit, BLASTn dan MEGA 6. Sekuen DNA parsial dari gen penyandi $18 S$ rRNA K. x laetivirens telah diperoleh dengan ukuran 419pb. Sekuen tersebut memiliki kemiripan sebesar 99,28\% dengan K. daigremontiana. Kalanchoe x laetivirens membentuk satu kelompok dengan sesama anggota dari famili Crassulaceae dan terpisah dari famili lainnya yang diteliti. Primer $18 S$ rRNA spesifik terhadap cocor bebek telah dirancang, yaitu forward 5'-CAA ATT ACC CAA TCC TGA CA -3' dan reverse 5'- CCA ACG TAA ATA GGA TCG AA -3'. Sekuen yang diperoleh pada penelitian ini berpotensi sebagai gen referensi setelah dilakukan validasi.

Kata kunci: $18 S$ rRNA; gen housekeeping; Kalanchoe x laetivirens; kontrol internal; PCR
\end{abstract}

\begin{abstract}
Plant stress studies are based on gene expressions. This study aims to analyze the DNA sequence of 18S rRNA in cocor bebek (K. x laetivirens). Methods being out are total DNA isolation using Mini Kit Genomic DNA Mini Kit Plant (Geneaid). The DNA sequence was analyzed utilizing BioEdit, BLASTn and Mega 6 programs. Partial DNA sequence of $18 S$ rRNA in K. x laetivirens has been obtained with $419 \mathrm{bp}$ length. The DNA sequence has $99.28 \%$ similarity to $K$. daigremontiana. Kalanchoe $x$ laetivirens formed one group with another species from the same family, Crassulaceae, based on the DNA sequence of $18 S$ rRNA. A primer pair specific to K. x laetivirens for amplifying $18 S$ rRNA has been designed such as forward 5'- CAA ATT ACC CAA TCC TGA CA -3' and reverse 5'- CCA ACG TAA ATA GGA TCG AA -3'. This DNA sequence is potentially being employed as an internal control once the validation process completed.
\end{abstract}

Keywords: $18 S$ rRNA; housekeeping gene; internal control; Kalanchoe x laetivirens; PCR

\section{PENDAHULUAN}

Cocor bebek atau nama ilmiahnya Kalanchoe $x$ laetivirens merupakan tumbuhan herba sukulen yaitu tumbuhan yang mengandung air (Ai 2012). Kalanchoe $x$ laetivirens termasuk ke dalam famili Crassulaceae yang diduga merupakan hasil persilangan antara $K$. laxiflora dengan $K$. daigremontiana (Shaw 2008). Cocor bebek merupakan tumbuhan yang kerap dijumpai pada daerah-daerah yang beriklim tropis seperti Asia, Australia, Galapagos, dan Hawaii (Kazmi et al. 2012).

Tumbuhan cocor bebek sudah turuntemurun digunakan oleh masyarakat sebagai tumbuhan hias dan juga tumbuhan obat (Latief 2012). Tumbuhan ini mudah tumbuh pada kondisi lingkungan kering dan panas dan tidak sulit dalam pemeliharaannya. Kemampuan adaptasi cocor bebek pada kondisi lingkungan tersebut menunjukkan bahwa ada gen-gen yang mengontrolnya. Untuk mempelajari pola ekspresi gen-gen 
tersebut diperlukan kontrol internal yang umumnya berasal dari kelompok gen housekeeping.

Syarat suatu gen dapat dijadikan sebagai kontrol internal ialah ekspresinya stabil dan ekspresinya terdapat pada semua jaringan. Beberapa gen housekeeping yang sudah dijadikan kontrol internal pada beberapa tumbuhan seperti 18S rRNA, 26S rRNA, glyceraldehyde-3-phosphate dehydrogenase (GAPDH), aktin dan elongation factor-1alpha (EF1 $\alpha)$ (Chen et al. 2015).

Gen penyandi 18S rRNA merupakan salah satu kontrol internal yang banyak digunakan dalam studi ekspresi gen karena gen tersebut diekspresikan pada semua jaringan, sel, dan berbagai perlakuan (Kuchipudi et al. 2012). Molekul 18S rRNA merupakan komponen dari subunit besar ribosom sel eukariotik (Meyer et al. 2010). Gen penyandi 18S rRNA berukuran $1800 \mathrm{pb}$ dan terletak di genom inti (Kwon et al. 1991).

Isolasi gen dari $18 \mathrm{~S}$ rRNA sebagai gen referensi sebelumnya sudah pernah dilakukan pada tumbuhan Gynura procumbens (Christiningrum et al. 2016), Capsicum annuum (Elsima et al. 2019), dan Platycladus orientalis (Chang et al. 2016). Namun, saat ini informasi mengenai gen referensi $18 \mathrm{~S}$ rRNA dari tumbuhan $K$. $x$ laetivirens belum diketahui dan belum diteliti. Oleh sebab itu, penelitian ini bertujuan untuk menganalisis sekuens DNA penyandi $18 \mathrm{~S}$ rRNA pada tumbuhan cocor bebek ( $K . x$ laetivirens). Sekuen ini belum pernah dilaporkan dari spesies tanaman ini dan nantinya dapat digunakan sebagai kontrol internal pada analisis ekspresi gen di tanaman ini setelah dilakukan validasi.

\section{METODE}

Penelitian dilakukan di Laboratorium Genetika, Jurusan Biologi, Fakultas Matematika dan Ilmu Pengetahuan Alam, Universitas Riau. Pengambilan sampel dilakukan di tanah kebun jalan Kuantan 7 Kota Pekanbaru, Provinsi Riau.

Bahan yang digunakan pada penelitian ini ialah daun segar dari tumbuhan $K$. $x$ laetivirens. Amplifikasi daerah target 18S rRNA ini menggunakan pasangan primer forward 5'- CGC GCA AAT TAC CCA ATC CTG ACA -3' dan reverse 5'- TCC CGA AGG CCA ACG TAA ATA GGA -3' (Gantasala et al. 2013). Amplifikasi menggunakan pasangan primer tersebut akan menghasilkan amplikon sekitar 400 pb.

Sampel daun untuk isolasi DNA diambil sebanyak 0,1 gram setelah itu dipotong lalu dibelah dan dibuang lendir yang berada di dalam daun. Daun kemudian digerus menggunakan mortar dan pestel dan ditambahkan dengan Nitrogen cair. Isolasi dilakukan menggunakan kit isolasi DNA tumbuhan Genomic DNA Mini Kit Plant (Geneaid) hingga didapatkan larutan DNA yang disimpan pada suhu $4^{\circ} \mathrm{C}$.

Amplifikasi daerah gen 18S rRNA dilakukan dengan teknik PCR. Larutan DNA yang telah diperoleh digunakan sebagai cetakan pada proses PCR (Hercuvan). Komponen dan program PCR mengikuti prosedur yang dilakukan oleh Roslim (2017).

Larutan DNA total maupun produk PCR dideteksi dengan teknik elektroforesis, yaitu dengan memigrasikan pada $1 \%$ gel agarosa menggunakan larutan buffer 1x TBE ( $\mathrm{pH} 8)$. Larutan $1 \mathrm{~kb}$ DNA ladder (Thermo Scientific) digunakan sebagai DNA standar.

Produk PCR dengan pita yang tunggal dan tebal dikirim ke PT. Genetika Science Indonesia untuk dilakukan sekuensing di $1^{\text {st }}$ Base Malaysia. Volume produk PCR yang dikirim sebanyak minimal $40 \mu \mathrm{l}$. Selain itu, juga dikirimkan primernya untuk keperluan sekuensing. Primer yang dikirim adalah 30 $\mu \mathrm{l}$ primer forward dan $30 \mu \mathrm{l}$ primer reverse.

Data sekuen DNA forward dan reverse yang diperoleh kemudian diolah menggunakan program BioEdit 7.0. Urutan sekuen DNA yang telah diperoleh selanjutnya dianalisis untuk mencari kemiripannya menggunakan progam BLASTn (Basic Local Alignment Search Tool) yang diakses secara online pada website NCBI. Matriks jarak genetik dan dendrogram dibuat menggunakan program MEGA (Molecular Evolutionary Genetics 
Analysis) versi 6.0. Dendrogram dikonstruksi dengan analisis NeighbourJoining Tree dan bootstrap 1000 Kali. Untuk merancang primer gen penyandi $18 \mathrm{~S}$ rRNA yang spesifik terhadap cocor bebek $(K . \quad x$ laetivirens) digunakan program primer3 yang diakses secara langsung melalui situs https://bioinfo.ut.ee/primer30.4.0\%.

\section{HASIL DAN PEMBAHASAN}

Molekul DNA total telah diperoleh dengan kondisi utuh, tidak terfragmentasi dan layak untuk PCR (Gambar 1). Isolasi DNA adalah langkah awal dalam proses analisis DNA. Isolasi DNA menggunakan kit merupakan salah satu metode cepat dan mudah untuk memurnikan DNA total.

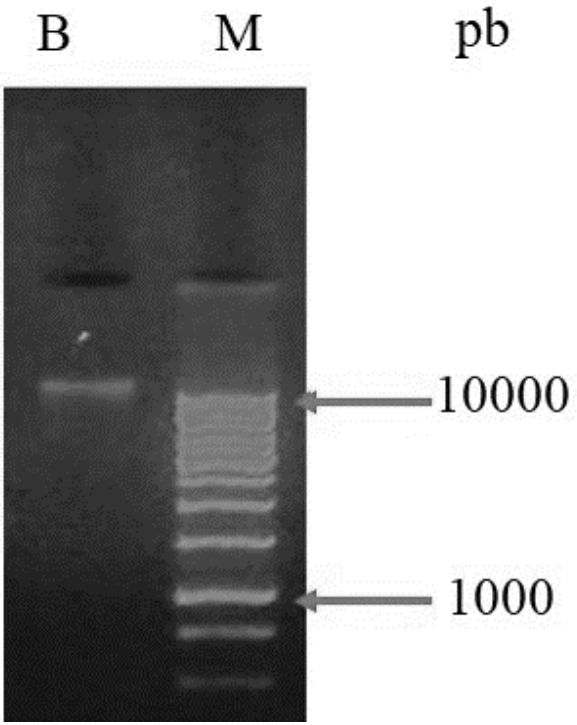

Gambar 1. Profil DNA total tumbuhan cocor bebek (Kalanchoe $x$ laetivirens). $\mathrm{pb}$ : pasang basa, M: $1 \mathrm{~kb}$ DNA ladder (Thermo Scientific), B: DNA total cocor bebek.

Produk PCR telah diperoleh dengan ukuran sekitar $400 \mathrm{pb}$. Fragmen DNA yang diperoleh tunggal, tebal dan layak untuk disekuensing (Gambar 2). Sekuen DNA yang diperoleh setelah berukuran $419 \mathrm{pb}$ (Gambar 3). Sekuen tersebut telah didaftarkan di database GenBank dengan nomor aksesi MW286358.

Sekuens yang telah disejajarkan dari tumbuhan cocor bebek mempunyai kemiripan tertinggi yaitu dengan $K$. daigremontiana (99,28\%). Dengan nilai Query cover 99\% (Tabel 1). Nilai Query cover menunjukkan bahwa sekuen penyandi 18S rRNA yang diperoleh $99 \%$ yang tersejajarkan atau teranalisis.

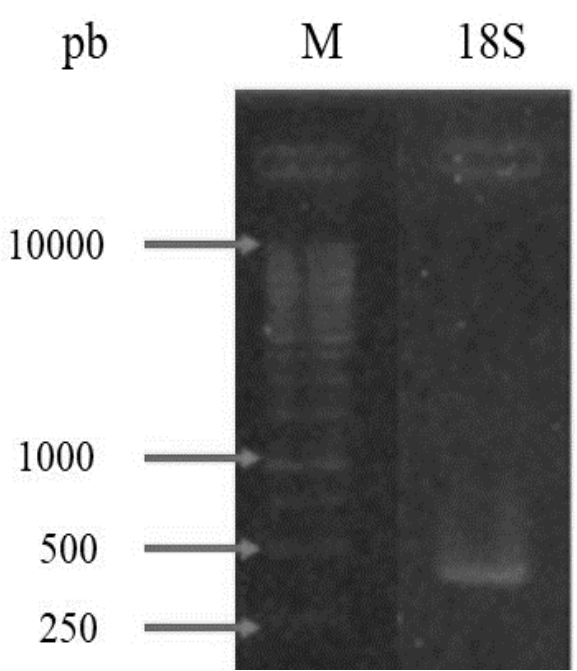

Gambar 2. Profil fragmen DNA penyandi $18 \mathrm{~S}$ rRNA tumbuhan cocor bebek. pb: pasang basa, M: $1 \mathrm{~kb}$ DNA ladder (Thermo Scientific), 18S: gen 18S rRNA.

\begin{abstract}
$>$ Kalanchoe $\mathbf{x}$ laetivirens_18S rRNA_419 pb
TCGCGCAAATTACCCAATCCTGACACGGGGAGGTAGTGACA ATAAATAACAATACCGGGCTCAATGAGTCTGGTAATTGGAA TGAGTACAATCTAAATCCCTTAACGAGGATCCATTGGAGGG CAAGTCTGGTGCCAGCAGCCGCGGTAATTCCAGCTCCAATA GCGTATATTTAAGTTGTTGCAGTTAAAAAGCTCGTAGTTGG ACCTTGGGTTGGGACGTCCGGTCCTCCTTTCGGTGTGCACC GGCCGTCTCGGCCCTTCTGCCGGCGATGCGCTCCTGGCCTT AACTGGCCGGGTCGTGCCTCCGGCGCTGTTACTTTGAAGAA ATTAGAGTGCTCAAAGCAAGCCTACGCTCTGTATACATTAG CATGGGATAACATCATAGGATTTCGATCCTATTTACGTTGG CCTTCGGGA
\end{abstract}

Gambar 3. Sekuens DNA 18S rRNA pada cocor bebek (Kalancboe $x$ laetivirens).

Nilai E-value 0,0 menunjukkan bahwa sampel memiliki derajat kesamaan yang tinggi. Semakin rendah nilai $E$-value, data akan semakin akurat. Nilai Ident menunjukkan persentase kemiripan sekuen yang disejajarkan. Semakin besar nilainya, semakin tinggi tingkat kesamaan dari sekuen yang disejajarkan. Sementara itu, karena perbedaan beberapa pasang basa nukleotida yang dianalisis, maka nilai identiti 10 aksesi tidak mencapai $100 \%$. 
Tabel 1. Hasil analisis BLASTn dari gen penyandi 18S rRNA pada tumbuhan cocor bebek (Kalanchoe x laetivirens)

\begin{tabular}{lllcccc}
\hline No & \multicolumn{1}{c}{ Spesies } & Famili & Total Scor Query Cover $(\%$ E & $\begin{array}{c}\text { Ident } \\
\text { value }\end{array}$ \\
& & & & & 0 & 99,28 \\
\hline 1 & Kalanchoe daigremontiana & Crassulaceae & 737 & 99 & 0 & 99,28 \\
2 & Dudleya viscida & Crassulaceae & 737 & 99 & 0 & 99,04 \\
3 & Kalanchoe pinnata & Crassulaceae & 733 & 99 & 0 & 98,33 \\
4 & Sedum rubrotinctum & Crassulaceae & 720 & 99 & 0 & 97,61 \\
5 & Cuttsia viburnea & Rousseaceae & 706 & 99 & 0 & 97,61 \\
6 & Carpodetus serratus & Rousseaceae & 706 & 99 & 0 & 97,37 \\
7 & Viburnum opulus & Adoxaceae & 701 & 99 & 0 & 97,37 \\
8 & Knautia arvensis & Caprifoliaceae & 701 & 99 & 0 & 97,37 \\
9 & Dipsacus asperoides & Dipsacaceae & 701 & 99 & 0 & 97,37 \\
10 & Pennantia cunninghamii & Pennantiaceae & 701 & 99 & & 0 \\
\hline
\end{tabular}
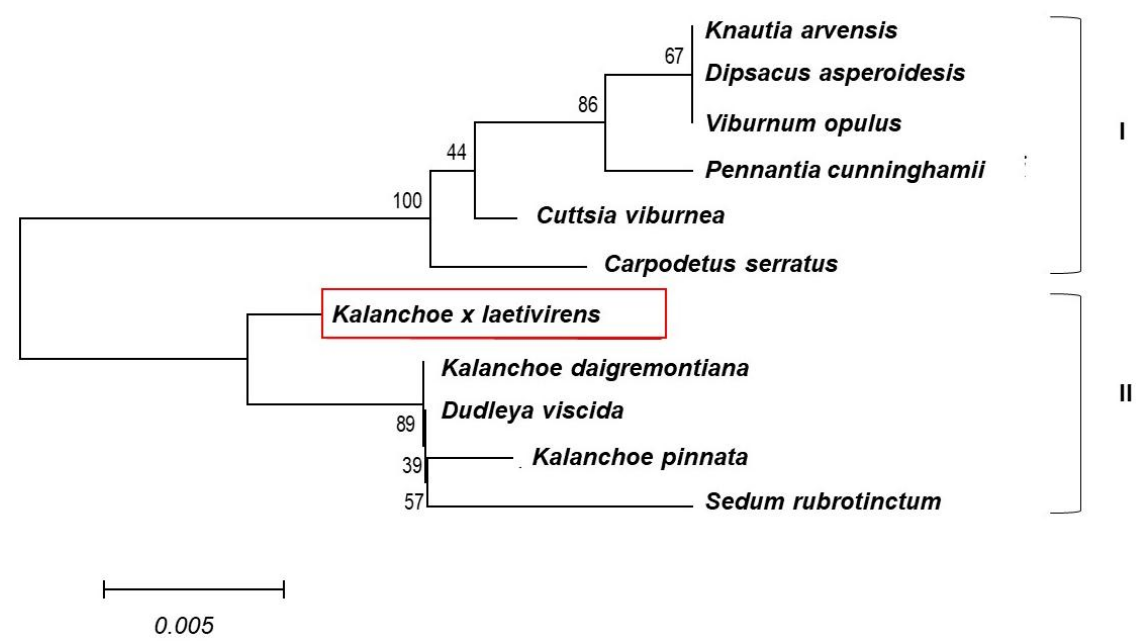

Gambar 4. Dendrogram berdasarkan sekuens DNA penyandi 18S rRNA dengan metode Neighbour-Joining dan Bootstarp 1000 Kali

Tabel 2. Primer 18S rRNA yang spesifik terhadap Cocor Bebek (K. x laetivirens)

\begin{tabular}{|c|c|c|c|c|c|}
\hline Primer & start & $\begin{array}{l}\text { Len } \\
\text { (pb) }\end{array}$ & $\begin{array}{l}\mathbf{T m} \\
\left({ }^{\circ} \mathrm{C}\right)\end{array}$ & GC\% & $\begin{array}{c}\text { Seq } \\
5 '-3\end{array}$ \\
\hline Forwar & 6 & 20 & 55,94 & 40,00 & CAAATTACCCAATCCTGACA \\
\hline Reverse & 410 & 20 & 55,35 & 40,00 & CCAACGTAAATAGGATCGAA \\
\hline
\end{tabular}

Dendrogram yang dikonstruksi berdasarkan sekuens DNA $18 \mathrm{~S}$ rRNA (Gambar 4) menunjukkan bahwa aksesi yang diteliti membentuk dua kelompok besar, yaitu kelompok I dan kelompok II. Kelompok I beranggotakan aksesi dari famili selain Crassulaceae, sedangkan kelompok II beranggotakan aksesi dari famili Crassulaceae. Tumbuhan cocor bebek
(K. $x$ laetivirens) yang diteliti berada di kelompok II.

Berdasarkan sekuen DNA yang telah diperoleh, telah dirancang primer 18S rRNA spesifik terhadap cocor bebek menggunakan program primer3 (Tabel 2). Panjang primer yang dirancang masing-masing $20 \mathrm{pb}$. Primer tersebut dapat digunakan dalam analisis ekspresi gen terkait cekaman 
lingkungan tertentu pada tumbuhan cocor bebek (K. x laetivirens).

\section{KESIMPULAN}

Sekuen DNA parsial penyandi $18 \mathrm{~S}$ rRNA pada $K$. x laetivirens yang didapatkan dari penelitian ini berukuran $419 \mathrm{bp}$. Sekuen tersebut memiliki kemiripan tertinggi sebesar 99,28\% dengan spesies $K$. daigremontiana. Kalanchoe $x$ laetivirens membentuk satu kelompok dengan sesama anggota dari famili Crassulaceae. Primer 18S rRNA spesifik terhadap cocor bebek telah dirancand dan primer tersebut dapat digunakan untuk keperluan validasi.

\section{UCAPAN TERIMAKASIH}

Penelitian ini dibiayai oleh DIPA FMIPA Universitas Riau dengan nomor 2407e/UN19.5.1.1.3/PL.01.00/2020.

\section{DAFTAR PUSTAKA}

Ai NS (2012) Evolusi Fotosintesis Pada Tumbuhan. J Ilmiah Sains 12: 28-34.

Chang E, Zhao Y, Wei Q, Shi S, Jiang Z (2016) Isolation of high-quality RNA from Platycladus orientalis and other Cupressaceae plants. Electronic Journal of Biotechnology 23: 21-27.

Chen C, Xie T, Ye S, Jensen AB, Eilenberg J (2015) Selection of reference genes for expression analysis in the entomophthoralen fungus Pandora neoaphidis. Brazilian Journal of Microbiology 47: 259-265.

Christiningrum OD, Budiharjo A, Kusdiyantini E (2016) Karakterisasi Molekuler Tanaman Sambung Nyawa (Gynura Procumbens [Lour.] Merr) Berdasarkan 18S rRNA. Jurnal Biologi 5: 60-70.

Elsima A, Ferniah RS, Kusumaningrum HP (2019) Ekspresi Gen Penyandi Peroksidase Cabai Merah (Capsicum annuum L.) (Caper) sebagai Respons terhadap Fusarium Oxysporum. Jurnal Akademika Biologi 8: 30-35.

Gantasala NP, Papolu PK, Thakur PK, Kamaraju D, Sreevathsa R, Rao U (2013) Selection and Validation of Reference Genes for Quantitative Gene Expression Studies by Real-Time PCR in Eggplant (Solanum melongena L). BioMed Central 6: 1-11.

Kazmi I, Khan R, Singh R, Chauhan M, Anwar F, Bist T (2012) Brophyllum Pinnatum A Review. Int. J. of Research in Biological Sciences 2: 143-149.

Kuchipudi SV, Tellabati M, Nelli RK, White GA, Perez BB, Sebastian S, Slomka MJ, Brookes SM, Brown IH, Dunham SP, Chang KC (2012) 18S rRNA is a Reliable Normalisation Gene for Real Time PCR Based on Influenza Virus Infected Cells. BioMed Central 9: 1-7.

Kwon O, Ogino K, Ishikawa H (1991) The longest 18s ribosomal RNA Ever Known Nucleotide Sequence and Presumed Secondary Structure of the 18s rRNA of the Pea Aphid, Acyrthosiphon pisum. J. Biochem 202 : 827-833.

Latief A (2012) Obat Tradisional. EGC, Jakarta.

Meyer A,Todt C, Mikkelsen NT, Lieb B (2010) Fast evolving 18S rRNA sequences from Solenogastres (Mollusca) Resist Standard PCR Amplification and Give New Insights Into Mollusk Substitution Rate Heterogeneity. BioMed Central 10: 2-12.

Roslim DI (2017). Identification of Pandan Plant (Benstonea sp) from Riau, Indonesia Using Three DNA Barcodes. SABRAO J Breed. and Genet. 49(4): 346-360.

Shaw JMH (2008) An investigation of the cultivated Kalanchoe daigremontiana group, with a checklist of Kalanchoe cultivars. Hanburyana 3: 17-79. 